\title{
Öğrenci Görüşlerine Göre Yükseköğretimde Kalite Göstergeleri (Kırklareli Üniversitesi Örneği) ${ }^{1}$
}

\section{According to Student Opinions Quality Indicators in Higher Education (Kırklareli University Case)}

\author{
Ertuğ $\mathrm{CAN}^{2}$
}

\begin{tabular}{|c|c|}
\hline $\begin{array}{l}\frac{\text { Anahtar }}{\text { Kelimeler }} \\
\text { Yüksekögrretim, } \\
\text { kalite, } \\
\text { eğitimde kalite, } \\
\text { yükseköğretimde } \\
\text { kalite. }\end{array}$ & 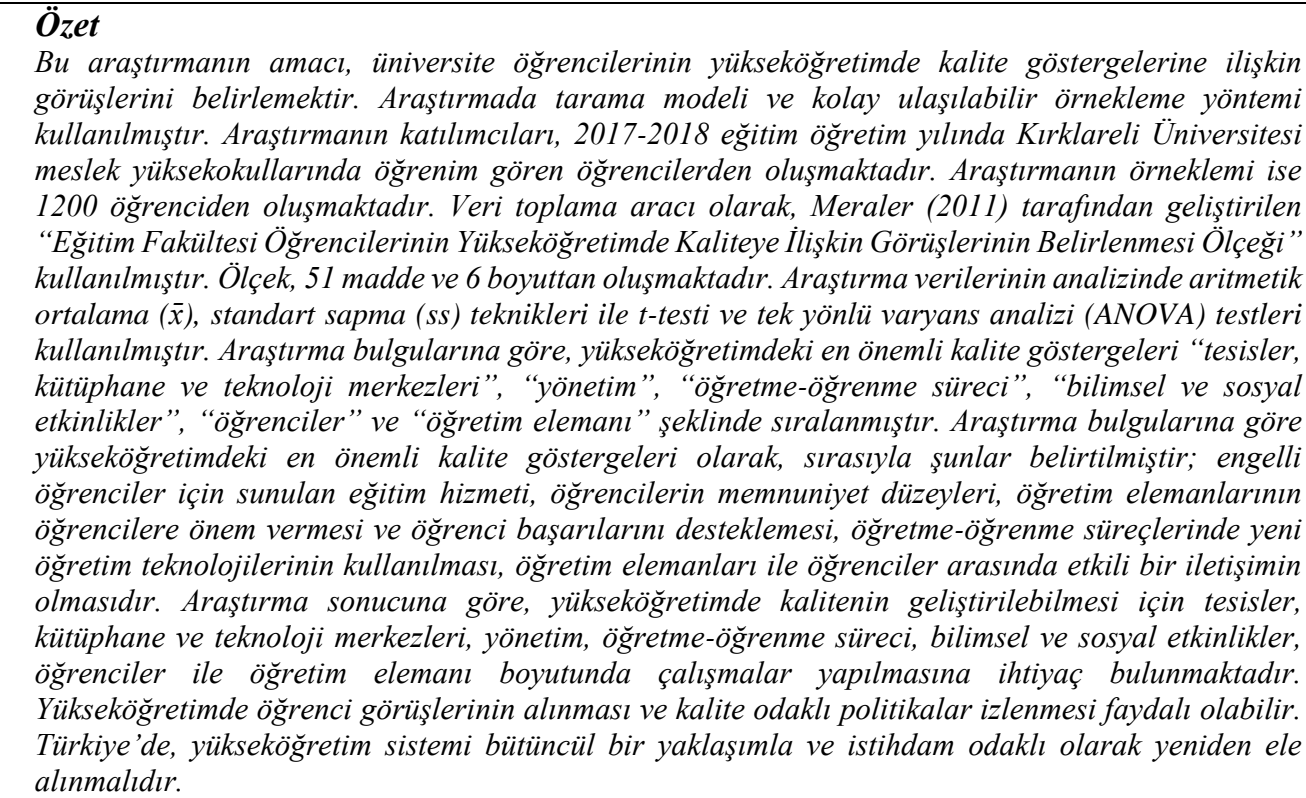 \\
\hline $\begin{array}{l}\text { Key Word } \\
\text { Higher } \\
\text { education, } \\
\text { quality, } \\
\text { quality in } \\
\text { edcucation, } \\
\text { quality in higher } \\
\text { education. }\end{array}$ & $\begin{array}{l}\text { Abstract } \\
\text { The purpose of this research is to determine the views of university students regarding the quality } \\
\text { indicators in higher education. Survey model and easily accessible sampling method were used in the } \\
\text { research. The participants of the research consist of students studying at vocational colleges at } \\
\text { Kirklareli University in } 2017-2018 \text { academic year. The sample of the research consists of } 1200 \\
\text { students. As the data collection tool, was used the "Determination of the Views of the Faculty of } \\
\text { Education Students on Quality in Higher Education Scale" developed by Meraler (2011). The scale } \\
\text { consists of } 51 \text { items and } 6 \text { dimensions. In the analysis of research data, arithmetic mean (x), standard } \\
\text { deviation (ss) techniques, t-test and one-way analysis of variance (ANOVA) tests were used. According } \\
\text { to the research findings, the most important quality indicators in higher education are listed as } \\
\text { "facilities, library and technology centers", "management", "teaching-learning process", "scientific } \\
\text { and social activities", "students" and "teaching staff". According to the research findings, the } \\
\text { following are stated as the most important quality indicators in higher education; Education service } \\
\text { for students with disabilities, satisfaction levels of students, teaching staffs give importance to students } \\
\text { and support student achievements, The use of new teaching technologies in teaching-learning } \\
\text { processes, is an effective communication between teaching staffs and students. According to the } \\
\text { research result, in order to improve the quality in higher education, there is a need for important } \\
\text { studies in terms of facilities, library and technology centers, management, teaching-learning process, } \\
\text { scientific and social activities, students and teaching staffs. It may be beneficial to take of student } \\
\text { views and follow quality-oriented policies in higher education. In Turkey, the higher education system } \\
\text { should be reconsidered as a holistic approach and employment-oriented. }\end{array}$ \\
\hline $\begin{array}{l}\text { Atıf için: } \\
\text { For Citation }\end{array}$ & $\begin{array}{l}\text { Can, E. (2021). Öğrenci Görüşlerine Göre Yükseköğretimde Kalite Göstergeleri (Kırklareli } \\
\text { Üniversitesi Örneği) Muğla Sitkı Koçman Üniversitesi Ĕ̆itim Fakültesi [MSKU Journal of } \\
\text { Education], 8(1), 54-71. DOI: 10.21666/muefd.754193 }\end{array}$ \\
\hline & Received: $17.06 .2020 \quad$ Accepted: $15.12 .2020 \quad$ Published: 01.05.2021 \\
\hline
\end{tabular}

\footnotetext{
${ }^{1}$ Bu araştırma, Uluslararası Pegem Eğitim Kongresi'nde (IPCEDU-2020) sözlü bildiri olarak sunulmuştur.

${ }^{2}$ Kirklareli Üniversitesi Fen Edebiyat Fakültesi, ertugcan@gmail.com. ORCID: 0000-0002-0885-9042
} 
Eğitimde kalite, son zamanlarda öğrenciler, öğretmenler, eğitim kurumları ve toplumun gündeminde olan konulardan biridir. Gencel'e (2001) göre, kalite kavramı kısaca bir ürünün ya da hizmetin ihtiyaçları karşılayabilme özelliğidir. Yükseköğretimde kalite ise, Özer, Gür \& Küçükcan'a (2010) göre, belli bir sistem, kuruluş, program veya disiplinin, belli standartlar ve hedefleri ile ilgili çok yönlü bir kavramdır. Ayrıca, yükseköğretimde kalitenin öğrenci, üniversite, toplum, devletin belirlediği kalite gereklilikleri, girdi, süreç, çıktı, misyon ve amaç ile akademik yaşama özgü nitelik ve özelliklere göre farklılaşabileceği belirtilmektedir. Karaboğa'nın (2018, s.22) belirttiği gibi, küresel olarak yükseköğretim talebinde meydana gelen artış, piyasa odaklı ihtiyaç ve beklentilerin artması, hızlı gelişen sosyal ve ekonomik değişimler ile birlikte toplumda ortaya çıkan nitelikli hizmet ve insan kaynağı beklentisi, sürekli büyüyen üniversitelerin eğitimle ilgili hizmetlerinde sistemli ve stratejik yaklaşımları gerektirmesi ile birlikte yükseköğretim kurumlarında kalite odaklı bir yönetim anlayışı gelişmeye başlamıştır.

Tüm öğretim kademelerinde olduğu gibi, yükseköğretimde yaşanan dönüşümde 1980 sonrasında izlenen neo-liberal ekonomi politikalarının da büyük etkisi olduğu söylenebilir. Neo-liberal ekonomi politikalarının eğitime etkileri incelendiğinde (Sayılan, 2007; Giroux, 2014; Yel, 2014; Hill, 2016; Tezcan, 2017); Neo-liberal ekonomi politikaları ile birlikte eğitim hizmetlerinin içeriği ve sunumunda büyük değişiklikler meydana gelmiştir. Özellikle, yükseköğretim sisteminin örgütlenişi, yönetimi, müfredatın yapısı, öğrenci başarısı, öğretim elemanlarının performansı, yöneticilerin seçilmesi ve konumu, piyasa beklentilerine göre şekillenmeye başlamıştır. Bilgi toplumu, yaşam boyu öğrenme, eğitim reformu, bilgi teknolojileri, yönetişim, performans kriterleri, dijital öğrenme ve enformasyon ekonomisi gibi kavramlar neo-liberal politikaların sonucu ortaya çıkmıştır. Ayrıca, eğitimde yaşanan özelleştirme uygulamaları ve tüketim toplumuna yönelim, rekabet, bireysel öğrenme, bireysel performans ve bireysel beceri gibi farklılıkları ön plana çıkaran eğitim uygulamaları yaygınlaşmaya başlamıştır. Neo-liberal ekonomi politikalarının eğitimi piyasa alanına dahil etmesiyle yönetici, öğretmen, veli ve öğrenci ilişkileri de piyasalaşmıştır. Eğitimde, öğrenci ve veli için müşteri kavramının kullanımı yaygın kabul görmüş, eğitim kurumlarının başarısında, performans, kalite, kalite güvence sistemleri, rekabet, müşteri ilişkileri, bireysel başarı gibi kriterler ön plana çıkmaya başlamıştır.

Neo-liberal ekonomi politikalarının eğitime yansıması ve küreselleşme ile birlikte yükseköğretimde meydana gelen talep artışı, yükseköğretimin finansmanında sıkıntılara neden olmuş ve yöneticiler kalite güvence sistemine daha çok önem vermeye başlamışlardır. Ancak, yükseköğretime yönelik kalite güvencesi uygulamalarının, yükseköğretim politikaları ile uyumlu olması gerekmektedir (Özer, Gür \& Küçükcan, 2010). Burgaz \& Ekinci'nin (2007) de belirttiği gibi, bilgi toplumu ile birlikte yeni bir kalite anlayışı ve rekabet ortaya çıkmış, stratejik plan kavramı ve uluslararası işbirliği ile toplumun eğitime yönelik ilgi, beklenti ve ihtiyaçlarının değişmesi, yükseköğretim sistemini doğrudan etkileyerek öğrenci memnuniyetinin ve beklentilerinin karşılanmasının önemini gündeme getirmiştir.

Türkiye'de yükseköğretimde kalite ile ilgili çalışmalar 1994 yılında bazı mühendislik programları ile başlamış, 1997 yılında Kalite Değerlendirme Projesi, 1998 yılında ise öğretmen yetiştirme programlarına yönelik akreditasyon ve kalite iyileştirme çalışmaları gerçekleştirilmiştir. Türkiye'de yükseköğretimde kalite güvencesi ile ilgili ilk sistematik çalışmalar 2001 yılında Bologna süreci ile başlamıştır (YÖK, 2019a).

Yükseköğretim Kurumlarında Akademik Değerlendirme ve Kalite Geliştirme Yönetmeliği (YÖDEK, 2006) ve Yükseköğretim Kurumlarında Akademik Değerlendirme ve Kalite Geliştirme Rehberi (YÖDEK, 2007) ile Yükseköğretim Kalite Güvencesi Yönetmeliğinin (YÖK, 2015) yayınlanmas1, yükseköğretimde ortak bir kalite anlayışı ve standartların belirlenmesi, üniversitelerin akreditasyonuna yönelik önemli düzenlemelerdir. Süreç içinde yükseköğretimde kalitenin geliştirilmesine yönelik değişik yasal düzenlemeler yapılmakla birlikte, Yükseköğretim Kalite Güvencesi ve Yükseköğretim Kalite Kurulu Yönetmeliği (YÖK, 2018a) gereğince, Türkiye'deki bütün devlet ve vakıf yükseköğretim kurumlarının kurum iç değerlendirme raporlarını her yıl hazırlayıp Yükseköğretim Kalite Kurulu'na (YÖKAK) sunarak beş yıl içinde birden az olmamak üzere YÖKAK tarafindan yürütülmekte olan kurumsal diş değerlendirme sürecinden geçmesi gerekir. YÖKAK'ın (2020) üniversitelerin kurumsal dış değerlendirme ve akreditasyon süreçlerinde esas aldığ ölçütlerin, kalite güvence sistemi, eğitim ve öğretim, araştırma ve geliştirme, yönetim sistemi ile toplumsal katkı olduğu görülmektedir. Ayrıca, YÖK'ün yükseköğretimde kalite çalışmalarına yönelik yasal düzenlemeler yapması ile birlikte üniversitelerin öğrenci memnuniyetini belirlemeye yönelik çalışmalara hız verdiği görülmektedir. Ancak, YÖK (2019a) verilerine göre, 2017 ve 2018 yıllarına ait kurum iç değerlendirme süreci sonunda 
eğitim-öğretim alanında tanımlanmış olan süreçlerin yeterli olgunluk düzeyinde olmadığı ve eğitimöğretime ilişkin süreçlerde iyileştirme yapılması gerektiği belirtilmektedir. Özellikle, yeterliği esas alan öğretim programlarının öğrenme-öğretme teknikleri ile ölçme ve değerlendirme yaklaşımlarında öğrencinin merkeze alındığı bir yapıda tasarlanması ve uygulanması önerilmektedir. Gencel'e (2001, s.213) göre, Türk yükseköğretim sisteminde finansman problemi ve kamu yönetim sistemindeki geleneksel anlayış nedeniyle hizmetler genelde etkin ve kaliteli olarak yapılamamaktadır.

Yükseköğretimin yaşadığı önemli değişimlerle birlikte, kurumlara kalite anlayışının yerleştirilmesi için, kaliteli faaliyette bulunma, kalitenin sürekli iyileştirilmesi ve belgelenmesi alanında çok farklı sistem ve anlayışlar kullanılmaya başlanmıştır (Güney, 2019, s.410). Yükseköğretimde kalite yönetiminde kullanılan en önemli yöntemlerden biri olarak akreditasyon (Gencel, 2001; Aktan \& Gencel, 2007; Rehber, 2007), ile yükseköğretimde yürütülen eğitimin belirli standartlara uygunluğunun belirlenmesi ve kurumun belirli dönemlerde kendisini değerlendirmesi amaçlanmaktadır. Ancak, Özer, Gür \& Küçükcan'a (2010) göre, YÖK dışında bir akreditasyon kurumu kurmak yerine, Türk yükseköğretim sisteminde kaliteyi olumsuz etkileyen problemlerin belirlenerek çözümü için çalışılması yükseköğretimdeki kaliteye ilişkin sorunların çözümü için daha sağlıklı olacaktır. Yükseköğretim kurumlarında kalite değerlendirmelerinde en çok kullanılan yöntemlerin başında kalite göstergeleri (Arslan, 2002) yer almaktadır. Yükseköğretimdeki kalite göstergelerine yönelik değişik sınıflandırmalar yapıldığı görülmektedir. Örneğin, fiziksel teknolojik ortam, yönetimsel, öğretimsel ve psikolojik ortama yönelik değişkenler (Stukalina, 2010), öğrenci bütünleşmesi, öğrenci destek birimleri, öğretim süreçleri ve öğrenme kaynakları (Hacıfazlığlu, 2006), fakülte yönetimi, öğretim elemanları, eğitim öğretim kaynakları, eğitim öğretim kalitesi ve üniversite destek hizmetleri (Deveci, 2012), öğrenci, öğretim elemanı, ögretim süreci, fiziksel, sosyal ve teknolojik olanaklar, bilimsel ve sosyal aktiviteler (Meraler, 2011), sosyal ve kültürel faaliyetler, araştırma geliştirme faaliyetleri, eğitim öğretimin izlenmesi, değerlendirilmesi ve kalite yönetimi, eğitim öğretimin süreç ve uygulamaları, eğitim öğretimin tasarımı ile eğitim öğretimin ortam ve kaynakları (Şimşek, İslim \& Öztürk, 2019), akademik danışmanlık ve rehberlik hizmetleri, akademik ve sosyal iklim, akademik hizmetler ve ilişkiler, kütüphane hizmetleri, yönetsel hizmetler, sağlık hizmetleri, öğrenci işleri, beslenme hizmetleri, fizikî mekânlar ve ulaşım hizmetleri, laboratuvarlar ve etkinlik alanları (Burgaz \& Ekinci, 2007) şeklinde sinıflandırmalar yapıldığı görülmektedir.

Yükseköğretimde ön plana çıkan kalite unsurlarını, Owlia, \& Aspinwall (1996, s.19), yeterli ve modern donanım ve tesisler, güzel çevre, ulaşım kolaylığı, destek hizmetler (barınma, spor, sosyal hizmetler) akademik personelin niteliği, öğrencilerin ihtiyaçlarının anlaşılması, programların öğrencilerin ihtiyaçlarına uygunluğu, hizmetlerin sunumu, öğrenci geribildirimlerinin değerlendirilmesi, güvenilirlik ve problemlerin çözülmesi, şeklinde sıralamaktadır. Bu unsurların yükseköğretim kurumlarında esas alınmasının kalitenin gelişmesine olumlu katkılar sağlayacağı söylenebilir. Elmacı, Poyraz \& Çalık'a (1999, s.115-116) göre, yükseköğretimde fizikî ve akademik altyap1, müfredat, ölçme ve değerlendirme, personelin istihdamı ve teşvik edilmesi, araştırmalar ve yayınlar, kurumun gelişim planı ile üniversite, sanayi ve toplum ilişkileri boyutunda kalite yönetiminin sağlanması gerekmektedir. Yükseköğretimde kalitenin öğretim elemanı, öğrenci, üniversitenin fiziksel ve sosyal olanakları, mezunların istihdamı ve yönetim olarak sıralanabilecek boyutları olduğu söylenebilir. Son yıllarda, yükseköğretimde kalitenin farklı göstergeleri ön plana çıkmaktadır. Akademik performanslarına göre üniversitelerin sıralamalarının yer aldığı URAP Raporuna (2019) göre, üniversitelerin kalite sıralamalarında bilimsel üretkenlik ve akademik ürünlerin kalitesi büyük önem taşımaktadır. URAP (2019) raporuna göre, dünyanın ilk 2500 üniversitesini sıralamada akademik üretkenlik göstergeleri olarak, makale sayısı, atıf sayısı, toplam bilimsel doküman sayısı, toplam yayın etkisi, toplam atıf etkisi ve uluslararası iş birliği olmak üzere toplam 6 gösterge esas alınmıştır. URAP (2019) raporuna göre, dünya sıralamasında dünyanın ilk 2500 üniversitesi arasına 82 Türk üniversitesi girebilmiştir. Bu sonuç, Türk yükseköğretim sisteminin bir bütün olarak bilimsel üretkenlik ve akademik ürünlerin kalitesini esas alacak bir kalite yaklaşımı ve politikalarına ihtiyaç bulunduğunu göstermektedir.

Kırklareli Üniversitesi Öğrenci Memnuniyeti Araştırmas1 (2020) sonucuna göre, üniversite öğrencilerinin sağlı hizmetleri, kütüphane hizmetleri, akademik ve sosyo-kültürel ortam, beslenme hizmetleri, ulaşım, güvenlik hizmetleri ile öğrenme ortamları başta olmak üzere pek çok alanda memnuniyet düzeylerinin düşük olduğu ve beklenti düzeylerinin ise yüksek olduğu sonucuna ulaşılmıştır. Bu sonuç göstermektedir ki, yükseköğretimde kalite konusunda üniversite öğrencilerinin görüşlerinin öğrenilmesi ve bu doğrultuda iyileştirici çalışmalar yapılması büyük önem taşımaktadır. 
Hamutoğlu, Ünveren-Bilgiç \& Elmas'a (2020) göre, yükseköğretim sürecinde kalitenin sağlanmasının en önemli unsurlarından birisi tüm paydaşların memnuniyetinin sağlanmasıdır. Bu paydaşlardan en önemlilerinden birisi kuşkusuz öğrencilerdir. Yükseköğretimde kalite için öğrencilerin görüş ve beklentileri doğrultusunda memnuniyetlerinin sağlanmasının çok önemli olduğu söylenebilir. $\mathrm{Bu}$ amaçla, yükseköğretimde öğrenciler başta olmak üzere, öğretim elemanı, personel, yöneticiler ve toplumun ilgi, ihtiyaç ve beklentileri esas alınarak, memnuniyetlerinin karşılanması büyük önem taşımaktadır.

\section{Araştırmanın Amacı}

Araştırmanın amacı, öğrencilerin yükseköğretimde kalite göstergelerine ilişkin görüşlerini ortaya koymaktır. Araştırmada cevap aranan sorular şunlardır:

1.Öğrencilerin yükseköğretimde kalite göstergelerine ilişkin görüşleri nelerdir?

2.Öğrencilerin yükseköğretimde kalite göstergelerine ilişkin görüşleri, demografik özelliklerine göre anlamlı bir farklılık göstermekte midir?

\section{Yöntem}

Yükseköğretim öğrencilerinin yükseköğretimde kalite göstergelerine ilişkin görüşlerini belirlemeyi amaçlayan bu araştırma, nicel araştırma deseninde yürütülmüştür. Araştırmada tarama modelinden yararlanılmıştır. Karasar'a (2019, s.111) göre, genel tarama modeli, çok fazla elemanın yer aldığı evren ile ilgili genel bir sonuca varmak için evrenin tümünden veya bir bölümünden alınacak bir örneklem veya grup üzerinde yapılabilen taramalardır.

Araştırma kapsamında öncelikle, öğrencilerin yükseköğretimde kalite göstergeleri ile ilgili görüşleri belirlenmiştir. Ardından, öğrencilerin yükseköğretimde kalite göstergeleri ile ilgili görüşleri demografik özelliklerine göre incelenmiştir.

\section{Evren ve Örneklem}

Araştırmanın evreni, 2017-2018 eğitim öğretim y1lında Kırklareli Üniversitesi'ne bağlı 7 Meslek Yüksekokulunda öğrenim gören öğrencilerden oluşmaktadır. Araştırmanın yürütüldüğü dönemde, araştırmacının meslek yüksekokulunda yönetici olması nedeniyle, meslek yüksekokullarında öğrenim gören öğrencilerin kalite ile ilgili görüşleri hakkında fikir sahibi olmak istemesi, yani problem durumunu yakından hissetmesi, öğrencilerin eğitimlerine yönelik istek ve beklentileri, araştırmanın meslek yüksekokullarında yürütülmesinde etkili olmuştur. Ayrıca, araştırmada amaçlı örnekleme yöntemi kapsamında evren ve örneklemin kolay ulaşılabilir olması da, araştırmanın meslek yüksekokullarında gerçekleştirilmesinde etkili olmuştur. 2017-2018 öğretim yılında Kırklareli Üniversitesi'ne bağl1 Meslek Yüksekokullarında toplam 14.469 öğrenci kayıtlıdır (YÖK, 2018b).

Araştırmada evreni oluşturan meslek yüksekokullarında öğrenim gören toplam öğrencilerin \%10'una ulaşılması ve araştırmaya katılması amaçlanarak 14.469 x $0,10=1.446$ öğrenciye tesadüfì olarak ulaşılmıştır. Ancak, 1200 ölçek elde edilebilmiştir. Bu örneklem sayısının, evreni temsil edecek nitelikte olduğu değerlendirilmiştir. Örneğin, 5000 kişinin yer aldığı bir evrenden alınan 356 kişilik örneklem büyüklüğü yeterli kabul edilmiştir (Anderson, 1990, aktaran; Balc1, 2004). Ölçeğin uygulamas1 sonucunda eksik ve yanlış doldurulan ölçekler çıkarıldıktan sonra 809 ölçek değerlendirmeye alınmıştır. Araştırmaya katılım sağlayan öğrencilerin kişisel özellikleri Tablo 1'de verilmiştir. Tablo 1 incelendiğinde, araştırmaya katılan ve örnekleme dahil edilen meslek yüksekokulu öğrencilerinin \%54.26'sı kadın, \%45.74'ü erkektir. Öğrencilerin yarıdan fazlasının (\%52.04) Meslekî ve Teknik Eğitim uygulayan liselerden mezun olduğu, çoğunluğunun Diğer Bölümler (\%40.82) ile TürkçeMatematik (\%39.7) bölümlerinden mezun oldukları görülmektedir. Araştırmaya katılan öğrencilerin \%20.89'u Babaeski, \%17.55'i Sosyal Bilimler, \%17.06's1 Lüleburgaz, \%13.97'si Pinarhisar, \%11.99'u Vize, \%11.62'si Sağlık Hizmetleri, \%6.92'si ise Teknik Bilimler Meslek Yüksekokulu'nda öğrenim görmektedir. Ayrıca, araştırmaya katılan öğrencilerin çoğunluğu I. Öğretim (\%67) ve 2.Sınıf (\%61.68) ögrencisidir. 
Tablo 1

Öğrencilerin Kişisel Özelliklerine İlişkin Frekans Dă̆llımları

\begin{tabular}{|c|c|c|c|}
\hline Kişisel Özellikler & Özellik Kategorileri & Frekans(f) & Yüzde(\%) \\
\hline \multirow[b]{2}{*}{ Cinsiyet } & Kadın & 439 & 54,26 \\
\hline & Erkek & 370 & 45,74 \\
\hline \multirow{8}{*}{ Mezun Olunan Lise } & Meslekî ve Teknik Eğitim Lisesi & 420 & 52,04 \\
\hline & Anadolu Lisesi & 188 & 23,3 \\
\hline & Genel Lise & 118 & 14,62 \\
\hline & İmam Hatip Lisesi & 53 & 6,57 \\
\hline & Diğer & 22 & 2,73 \\
\hline & Anadolu Öğretmen Lisesi & 3 & 0,37 \\
\hline & Sosyal Bilimler Lisesi & 2 & 0,25 \\
\hline & Güzel Sanatlar Lisesi & 1 & 0,12 \\
\hline \multirow{5}{*}{ Lise Alanı } & Diğer & 329 & 40,82 \\
\hline & Türkçe-Matematik & 320 & 39,7 \\
\hline & Fen Bilimleri & 74 & 9,18 \\
\hline & Sosyal Bilimler & 63 & 7,82 \\
\hline & Yabanci Dil & 20 & 2,48 \\
\hline \multirow{7}{*}{ Öğrenim Görülen MYO } & Babaeski MYO & 169 & 20,89 \\
\hline & Sosyal Bilimler MYO & 142 & 17,55 \\
\hline & Lüleburgaz MYO & 138 & 17,06 \\
\hline & Pınarhisar MYO & 113 & 13,97 \\
\hline & Vize MYO & 97 & 11,99 \\
\hline & Sağlık Hizmetleri MYO & 94 & 11,62 \\
\hline & Teknik Bilimler MYO & 56 & 6,92 \\
\hline \multirow[t]{2}{*}{ Sinif } & 2. Sinif & 499 & 61,68 \\
\hline & 1. Sinif & 310 & 38,32 \\
\hline \multirow[t]{2}{*}{ Öğrenim Türü } & I. Öğretim & 542 & 67 \\
\hline & II. Öğretim & 267 & 33 \\
\hline
\end{tabular}

\section{Veri Toplama Aracı}

Araştırma verilerini toplayabilmek için Meraler'in (2011) geliştirmiş olduğu "Eğitim Fakültesi Öğrencilerinin Yükseköğretimde Kaliteye İlişkin Görüşlerinin Belirlenmesi Ölçeği”, kullanılmıştır. Öncelikle, yazardan ölçeğin kullanımı için gerekli izinler alınmıştır. Araştırma için, Kırklareli Üniversitesi Rektörlüğü Bilimsel Araştırmalar ve Yayın Etiği Kurulundan 35523585-199-E.8725 sayılı Etik Kurulu Onayı alınmıştır. Ayrıca, verilerin toplanmasında Üniversite yönetiminden yazılı olarak izin alınmıştır. Katılımcılar bilgilendirilmiş olur/onam formunu, gönüllü katılım formunu doldurduktan/onayladıktan sonra araştırma gönüllü katılımcılar ile yürütülmüsştür. Ölçek, "tesisler, kütüphane ve teknoloji merkezleri”, "öğretim elemanı", "öğrenciler", "yönetim”, "öğretme-öğrenme süreci" ile "bilimsel ve sosyal etkinlikler" olmak üzere, 6 bölümden oluşmaktadır. Ölçekte "öğrenciler" alt boyutunda yer alan iki soru üzerinde çalışma grubuna uygun olarak ölçek sahibinden izin alınarak düzenlemeler, uyarlamalar yapılmıştır. Bu amaçla, uzman desteği sağlanmıştır. Örneğin; "ÖSS puanları" ifadesinde ÖSS'nin günümüzde isminin değişmesi nedeniyle "üniversiteye giriş puanları" şeklinde düzenlenmiştir. Ayrıca, Ölçeğin ön lisans öğrencilerine uygulanması nedeniyle, "öğrencilerin lisansüstü eğitime kabul edilmesi” maddesi, "lisans eğitimine kabul edilmesi”" şeklinde düzenlenmiştir. Veri toplama aracında toplam 51 madde bulunmaktadır. Ölçek maddeleri, beşli likert tipi bir ölçek olarak derecelendirilmiştir. Ölçeğin seçenekleri en olumlu olandan en olumsuz seçeneğe doğru $5^{\text {'ten }}$ 1'e doğru puanlama yapılmıştır. Ölçekteki maddeler, "hiç katılmıyorum" için 1, "çok az katılıyorum" için 2, "biraz katılıyorum" için 3, "oldukça katılıyorum" için 4 ve "tamamen katılıyorum" için 5 puan ile değerlendirilmiştir. Ölçme aracındaki her bir madde için alt ve üst sınırlar belirlenmiştir. Bu amaçla ölçek maddelerinde, tamamen katıliyorum ve oldukça katılıyorum "yeterli düzey" (3.40-5.00), biraz katılıyorum "orta düzey" (2.60-3.39) ve çok az katılıyorum ile hiç katılmıyorum ise "yetersiz düzey" (1.00-2.59) olarak değerlendirilmiştir. Meraler (2011) tarafından ölçeğin güvenirlik katsayısı 0.926 olarak elde edilmiştir.

Ölçeğe ilişkin güvenirlik analizleri yeniden yapılarak Tablo 2'de verilmiş̧ir. 
Tablo 2

Ölçek ve Bu Ölçeğin Alt Boyutlarına İlişkin Güvenirlik(A) Düzeyleri

\begin{tabular}{ll}
\hline Ölçek Alt Boyutları & Cronbach Alfa( $(\boldsymbol{\alpha})$ \\
\hline Öğrenciler & 0,745 \\
\hline Öğretim Elemanı & 0,796 \\
\hline Öğretme-Öğrenme Süreci & 0,809 \\
\hline Tesisler, Kütüphane ve Teknoloji Merkezleri & 0,842 \\
\hline Yönetim & 0,827 \\
\hline Bilimsel ve Sosyal Etkinlikler & 0,901 \\
\hline ÖLÇEK (Genel) & 0,947 \\
\hline
\end{tabular}

Tablo 2 incelendiğinde, ölçeğin alt boyutlarına ait tüm Cronbach $\operatorname{Alfa}(\alpha)$ değerleri için $\alpha \geq 0,70$ olduğundan ölçme aracı güvenilirdir. Ölçeğin genel olarak güvenirliği 0.947 olarak bulunmuştur. $\mathrm{Bu}$ sonuç, ölçeğin güvenilir olduğunu göstermektedir.

\section{Verilerin Analizi}

Verilerin analizi SPSS 22.0 programı ile gerçekleştirilmiştir. Yükseköğretim öğrencilerinin yükseköğretimde kalite göstergelerine ilişkin görüşlerini belirleyebilmek amacıyla aritmetik ortalama $(\bar{x})$ ve standart sapma (ss) teknikleri kullanılmıştır. Araştırmaya katılan öğrencilerin görüşlerinin demografik özelliklerine göre anlamlı bir farklılık gösterip göstermediği aritmetik ortalama $(\overline{\mathrm{x}})$, standart sapma (ss), t testi ve tek yönlü varyans analizi (ANOVA) ile belirlenmeye çalışılmıştır. Araştırma kapsamında yapılan tüm hipotez testlerinde anlam düzeyi $(\alpha=0,05)$ olarak alınmıştır.

\section{Bulgular}

$\mathrm{Bu}$ bölümde, katılımcıların ölçek sorularına vermiş oldukları yanıtların istatistiksel analiz sonuçları yer almaktadır.

Öğrencilerin ölçeğin 6 alt boyutuna verdikleri cevaplara ilişkin aritmetik ortalama $(\bar{x})$ ve standart sapma (ss) değerleri Tablo 3'te sunulmuştur.

Tablo 3

Ölçeğin Geneline Yönelik Ortalama $(\bar{x})$ ve Standart Sapma(ss) Değerleri

\begin{tabular}{lll}
\hline Madde & Ortalama $(\overline{\mathbf{x}})$ & Standart Sapma $(\mathbf{s s})$ \\
\hline Tesisler, Kütüphane ve Teknoloji Merkezleri & 4,08 & 0,80 \\
\hline Yönetim & 4,06 & 0,85 \\
\hline Öğretme- Öğrenme Süreci & 3,88 & 0,75 \\
\hline Bilimsel ve Sosyal Etkinlikler & 3,86 & 0,73 \\
\hline Öğretim Elemanı & 3,56 & 0,79 \\
\hline Öğrenciler & 3,52 & 0,73 \\
\hline
\end{tabular}

Tablo 3 incelendiğinde, araştırmaya katılan öğrencilerin en önemli gördükleri boyutların sırasıyla "tesisler, kütüphane ve teknoloji merkezleri" $(4,08 \pm 0,80)$, "yönetim" $(4,06 \pm 0,85)$, "ögretme-ögrenme süreci" $(3,88 \pm 0,75)$, "bilimsel ve sosyal etkinlikler" $(3,86 \pm 0,73)$ boyutları olduğu; diğerlerine göre daha önemsiz gördükleri boyutların ise "ögrenciler" $(3,52 \pm 0,73)$ ve "ögretim elemanı" $(3,56 \pm 0,79)$ boyutları olduğu görülmektedir.

Araştırmaya katılan öğrencilerin öğrenim gördükleri bölümü tercih etme nedenleri Tablo 4'te sunulmuştur. Tablo 4 incelendiğinde, öğrencilerin büyük bir çoğunluğunun $(\% 46,6)$ "eğitim aldiğım alan ile ilgili meslek sahibi olmak" ve bir bölümünün de $(\% 34,73)$ öğrenim gördükleri bölümün "iş olanağ olması" nedeniyle bölümü tercih ettikleri görülmektedir. Öğrencilerin \%12,61'i "diğer" nedenler, \%6.06'sı ise "ailelerinin isteğì" nedeniyle öğrenim gördükleri bölümü tercih etmişlerdir. 
Tablo 4

Öğrencilerin Bölümü Tercih Etme Nedenlerine Göre Frekans Dağılımları

\begin{tabular}{lll}
\hline Bölüm Tercih Nedeni & Frekans $(\mathbf{n})$ & Oran $\mathbf{( \% )}$ \\
\hline Eğitim aldığım alan ile ilgili meslek sahibi olmak için & 377 & 46,6 \\
\hline İş olanağı olduğu için & 281 & 34,73 \\
\hline Diğer & 102 & 12,61 \\
\hline Ailem istediği için & 49 & 6,06 \\
\hline Toplam & $\mathbf{8 0 9}$ & $\mathbf{1 0 0}$ \\
\hline
\end{tabular}

Yükseköğretimde kaliteyi etkileyen faktörlerden olan ve ölçekte yer alan "öğrenciler" alt boyutuna ilişkin öğrenci görüssleri incelendiğinde araştırmaya katılan öğrencilerin ölçeğin "öğrenciler” boyutuna ait en önemli buldukları kalite göstergesinin "engelli ögrencilere sunulan eğitim hizmetlerinin yeterliliği" olduğu $(4,14 \pm 1,12)$; en önemsiz görülen kalite göstergesinin ise "üniversitenin ögrenci sayısının fazla olması" olduğu $(2,79 \pm 1,41)$ görülmektedir. Ayrıca, öğrencilere göre, yükseköğretimde "öğrenciler" boyutu altında, yeterli düzeydeki diğer kalite göstergeleri olarak sırasıyla, öğrencilerin üniversiteden memnuniyeti, öğrencilerin üniversiteye giriş puanlarının yüksek olması, ön lisans mezunu öğrencilerin lisans programlarına kabul edilme oranları, öğrencilerin mezuniyet notunun yüksek olması, mezun öğrencilerin iş bulma olanağı, şeklinde sıralanmıştır. Araştırmaya katılan öğrenciler, üniversiteden mezun olan öğrenci sayısının fazla olması ile öğrencilerin mezun oldukları lise türünü, orta düzeyde bir kalite göstergesi olarak belirtmişlerdir.

Araştırmaya katılan öğrencilerin ölçeğin "öğretim elemanı" alt boyutuna ilişkin görüşlerine göre, en önemli buldukları kalite göstergesinin "ögrretim elemanlarının ögrencileri önemsemesi" olduğu $(4,05 \pm 1,15)$; en önemsiz görülen kalite göstergesinin ise "yabancı uyruklu ögretim elemanlarının sayısı" olduğu $(2,92 \pm 1,36)$; görülmektedir. Ayrıca, öğrencilere göre, ölçeğin “öğretim elemanı” alt boyutunda yükseköğretimde kalite göstergesi olarak sırasıyla, öğretim elemanlarının öğrenci başarılarını desteklemesi, öğretim elemanlarının öğrencileri tarafından yeterli görülmesi ve öğretim elemanlarının sayısal yeterliliği olarak sıralanmıştır. Öğrenciler, öğretim elemanı alt boyutunda yer alan ölçek maddelerini genel olarak yeterli düzeyde kalite göstergesi olarak değerlendirmişlerdir.

Öğrencilerin ölçeğin "öğretme- ögrrenme süreci" alt boyutuna ilişkin en önemli buldukları kalite göstergelerinin "yeni öğretim teknolojilerinin kullanılması" $(4,10 \pm 108)$ ve "öğretim elamanı ile ögrrenci arasındaki etkili iletişim" olduğu $(4,09 \pm 1,09)$; diğerlerine göre en önemsiz görülen kalite göstergesinin ise "öğrenci başarısını değerlendirmede kullanılan yaklaşımlar" olduğu $(3,60 \pm 1,18)$ görülmektedir. Öğrencilerin, "öğretme-öğrenme süreci”" alt boyutunda yer alan tüm maddeleri yeterli düzeyde kalite göstergesi olarak değerlendirdikleri görülmektedir.

Araştırmaya katılan öğrencilerin ölçeğin "tesisler, kütüphane ve teknoloji merkezleri” boyutunda en önemli buldukları kalite göstergesinin "derslik, atölye ve laboratuvar vb. ögretim ortamlarının yeterliği" olduğu $(4,29 \pm 1,02)$; diğerlerine göre en önemsiz görülen kalite göstergesinin ise "üniversitenin akademik birimleri ile programların saylsal yeterliği” olduğu $(3,73 \pm 1,14)$ görülmektedir. Ancak, bu boyut, öğrenciler tarafindan kalite göstergesi olarak "oldukça katıllyorum” düzeyinde değerlendirmiştir. Yani, bu alt boyutta yer alan tüm maddeler öğrencilere göre, yeterli düzeyde kalite göstergesi olarak değerlendirilmiştir.

Araştırmaya katılan öğrencilerin ölçeğin “yönetim” boyutuna ilişkin en önemli buldukları kalite göstergesinin "yönetimin ögrrenci sorunlarını ciddiye alması" olduğu $(4,23 \pm 1,04)$; ayrıca, "üniversitede karar verme sürecinde ögrrenci görüşlerini dikkate alma" $(4,15 \pm 1,08)$, "üniversitede demokratik bir ortamin olması" $(4,08 \pm 1,13)$ ve "yönetimin tüm personel ile olumlu ilişkiler kurması" $(4 \pm 1,1)$ da kalite göstergesi olarak değerlendirilmiş̧ir. Diğer maddelere göre daha düşük düzeyde değerlendirilen kalite göstergesinin ise "üniversite çalışanlarının yönetimden memnun olmaları" olduğu $(3,85 \pm 1,15)$ görülmektedir. Görüldüğü gibi, araştırmaya katılan öğrenciler "yönetim" alt boyutunda yer alan maddeleri "oldukça katılıyorum" düzeyinde değerlendirmişlerdir. Yani, öğrenciler yönetim alt boyutunda yer alan tüm maddeleri yeterli düzeyde kalite göstergesi olarak görmektedir.

Araştırmaya katılan öğrencilerin ölçeğin "bilimsel ve sosyal etkinlikler" boyutuna ilişkin en önemli buldukları kalite göstergesinin "üniversitenin dünyadaki en iyi üniversiteleri siralamasindaki konumu" olduğu $(4,31 \pm 1,06)$; en önemsiz görülen kalite göstergesinin ise "üniversitenin kuruluş tarihinin eski olmasl" olduğu $(2,98 \pm 1,39)$ görülmektedir. 


\section{Öğrencilerin Yükseköğretimde Kalite Göstergeleri İle İlgili Görüşlerinin Demografik}

\section{Özelliklere Göre Değerlendirilmesi}

Bu bölümde, öğrencilerin yükseköğretimde kalite göstergelerine ilişkin görüşlerinin cinsiyet, sınıf düzeyi, mezun olduğu lise, lise alanı, bölümü tercih nedeni gibi demografik özellikleri ile ilişkisine yer verilmiştir.

Öğrencilerin yükseköğretimde kalite göstergelerine ilişkin görüşleri ile cinsiyet arasında anlamlı bir farklılık var mıdır?

Öğrencilerin yükseköğretimde kalite göstergelerine ilişkin görüşleri ile "cinsiyet" değişkeni arasında anlamlı bir farklılık olup olmadığına ilişkin t-testi sonucu Tablo 5'te sunulmuştur.

Tablo 5

“Cinsiyet” Değişkenine Göre Ölçek Ortalamalarına İlişskin t-Testi Tablosu

\begin{tabular}{lllllll}
\hline Cinsiyet & $\mathbf{n}$ & Ortalama( $(\overline{\mathbf{x}})$ & Standart Sapma(ss) & t & sd & p \\
\hline Kadın & 439 & 3,82 & 0,60 & & & \\
\hline Erkek & 370 & 3,78 & 0,62 & 807 & 0,472 \\
\hline
\end{tabular}

Tablo 5 incelendiğinde, öğrencilerin yükseköğretimde kalite göstergelerine ilişkin görüşlerinin düzeylerinde cinsiyet bakımından istatistiksel olarak anlamlı bir fark bulunmamıştır ( $\mathrm{t}_{807}=0,719$, p > $0,05)$. Bu sonuca göre, öğrencilerin cinsiyeti yükseköğretimde kalite göstergeleri ile ilgili görüşlerini etkilememektedir.

Öğrencilerin yükseköğretimde kalite göstergelerine ilişkin görüşleri ile öğrenim gördükleri sınıf arasında anlamlı bir farklılık var mıdır?

Öğrencilerin yükseköğretimde kalite göstergelerine ilişkin görüşleri ile "sınıf" değişkeni arasında anlamlı bir farklılık olup olmadığına ilişkin t-testi sonucu Tablo 6' da sunulmuştur.

Tablo 6

"Sinıf" Deüiskenine Göre Ölçek Ortalamalarına İliskin t- Testi Tablosu

\begin{tabular}{|c|c|c|c|c|c|c|}
\hline Sinıf & $\mathbf{n}$ & Ortalama $(\overline{\mathbf{x}})$ & $\begin{array}{l}\text { Standart } \\
\text { Sapma(ss) }\end{array}$ & $\mathbf{t}$ & sd & $\mathbf{p}$ \\
\hline 1.Sinif & 310 & 3,78 & 0,67 & & & \\
\hline 2.Sinıf & 499 & 3,81 & 0,57 & $-0,592$ & 575,14 & 0,554 \\
\hline
\end{tabular}

Tablo 6 incelendiğinde, öğrenci görüşlerinde sınıf düzeylerine göre istatistiksel olarak anlamlı bir farka rastlanmamıştır $\left(\mathrm{t}_{575,14}=-0,592, \mathrm{p}>0,05\right)$. Bu sonuca göre, meslek yüksekokulu öğrencilerinin öğrenim gördükleri sınıf düzeyi, yükseköğretimde kalite göstergelerine ilişkin görüşlerini etkileyen bir faktör değildir.

Öğrencilerin yükseköğretimde kalite göstergelerine ilişkin görüşleri ile mezun oldukları lise türü arasında anlamlı bir farklılık var mıdır?

Yükseköğretimde kalite göstergeleri ile ilgili öğrenci görüşlerinin "mezun olunan lise" türüne göre anlamlı bir farklılık gösterip göstermediği ile ilgili varyans analizi sonucu Tablo 7'de sunulmuştur. Tablo 7 incelendiğinde, öğrencilerin yükseköğretimde kalite göstergelerine ilişkin görüşleri ile mezun oldukları lise türü arasında istatistiksel olarak anlamlı bir farka rastlanmamıştır $\left(\mathrm{F}_{3 ; 803}=0,691, \mathrm{p}>0,05\right)$. Öğrencilerin mezun oldukları lise değişkenine göre görüşlerinin aritmetik ortalamaları $(\overline{\mathrm{x}}=3,73)$ ile $(\overline{\mathrm{x}}$ $=3,86$ ) arasında değişim göstermektedir. Bu sonuca göre, Genel Liselerden mezun olan öğrenciler ölçekteki maddelere daha çok $(\bar{x}=3,86)$ katılım sağlarken, en düşük oranda ise $(\bar{x}=3,73)$ aritmetik ortalama ile Diğer Liselerden (Özel Liseler, Açıköğretim Lisesi, Sosyal Bilimler Lisesi, İmam Hatip Lisesi, Fen Lisesi, Güzel sanatlar Lisesi vb..) mezun olan öğrenciler katılım göstermişlerdir. Veri toplama aracında yer alan maddelerin yükseköğretimde kalite göstergesi olduğuna Anadolu Lisesi ile Meslekî ve Teknik Eğitim Uygulayan Liselerden mezun olan öğrencilerin ise ( $\bar{x}=3,80)$ aritmetik ortalama ile eşit oranda katıldıkları görülmektedir. 
Tablo 7

“Mezuniyet Lise Türü” Değişsenine Göre Ölçek Ortalamalarına İlişsin Varyans Analizi Tablosu

\begin{tabular}{|c|c|c|c|c|c|c|c|c|c|}
\hline Lise Türü & $\mathrm{n}$ & $\begin{array}{l}\text { Ortalama } \\
(\overline{\mathbf{x}})\end{array}$ & $\begin{array}{l}\text { Standart } \\
\text { Sapma(ss) }\end{array}$ & $\begin{array}{l}\text { Varyansın } \\
\text { Kaynağı }\end{array}$ & $\begin{array}{l}\text { Kareler } \\
\text { Toplamı }\end{array}$ & sd & $\begin{array}{l}\text { Kareler } \\
\text { Ortalaması }\end{array}$ & $\mathbf{F}$ & $\mathbf{p}$ \\
\hline Genel Lise & 118 & 3,86 & 0,56 & Gruplar & & & & & \\
\hline Anadolu Lisesi & 188 & 3,80 & 0,63 & aras1 & 0,77 & 3 & 0,257244 & & \\
\hline $\begin{array}{l}\text { Meslekî ve } \\
\text { Teknik Eğitim } \\
\text { Lisesi }\end{array}$ & 420 & 3,80 & 0,62 & Grup içi & 299,138 & 803 & 0,372526 & 0,69 & 0,56 \\
\hline Diğer Liseler & 81 & 3,73 & 0,58 & & & & & & \\
\hline Genel & 807 & 3,80 & 0,61 & Toplam & 299,910 & 806 & & & \\
\hline
\end{tabular}

Öğrencilerin yükseköğretimde kalite göstergelerine ilişkin görüşleri ile lise alanları arasında anlamlı bir farklılık var mıdır?

Yükseköğretimde kalite göstergeleri ile ilgili öğrenci görüşlerinin "lise alanı" değişkenine göre anlamlı bir farkl1lık gösterip göstermediği ile ilgili varyans analizi sonucu Tablo 8'de sunulmuştur.

Tablo 8

“Lise Alanı” Değişkenine Göre Ölçek Ortalamalarına İlişkin Varyans Analizi Tablosu

\begin{tabular}{|c|c|c|c|c|c|c|c|c|c|}
\hline Lise Alanı & $\mathbf{n}$ & $\begin{array}{l}\text { Ortalama } \\
(\overline{\mathbf{x}})\end{array}$ & $\begin{array}{l}\text { Standart } \\
\text { Sapma(ss) }\end{array}$ & $\begin{array}{l}\text { Varyansın } \\
\text { Kaynağı }\end{array}$ & $\begin{array}{l}\text { Kareler } \\
\text { Toplamı }\end{array}$ & sd & $\begin{array}{l}\text { Kareler } \\
\text { Ortalaması }\end{array}$ & F & $\mathbf{p}$ \\
\hline Fen Bilimleri & 74 & 3,85 & 0,52 & Gruplar & & & & \multirow{6}{*}{0,807} & \multirow{6}{*}{0,521} \\
\hline Türkçe- Mat. & 320 & 3,81 & 0,61 & aras1 & 1,202 & 4 & 0,300 & & \\
\hline Sosyal Bilim. & 63 & 3,85 & 0,71 & \multirow[t]{2}{*}{ Grup içi } & & & & & \\
\hline Yabancı Dil & 20 & 3,96 & 0,38 & & 298,316 & 801 & 0,372 & & \\
\hline Diğer & 329 & 3,77 & 0,62 & \multirow{2}{*}{ Toplam } & \multirow{2}{*}{299,518} & \multirow{2}{*}{805} & & & \\
\hline Genel & 806 & 3,80 & 0,61 & & & & & & \\
\hline
\end{tabular}

Tablo 8 incelendiğinde, öğrencilerin yükseköğretimde kalite göstergelerine ilişkin görüşlerinin düzeylerinde lise alanlarına göre, istatistiksel olarak anlamlı bir farka rastlanmamıştır $\left(F_{4 ; 801}=0,807, p\right.$ > $0,05)$. Öğrencilerin lisedeki alan değişkenine göre görüş ortalaması $(\bar{x}=3,77)$ ile $(\bar{x}=3,96)$ arasında değişim göstermektedir. Veri toplama aracında yer alan maddelere $(\overline{\mathrm{x}}=3,96)$ aritmetik ortalama ile lise alanı Yabancı Dil olan öğrenciler yüksek oranda katılım gösterirken, en düşük oranda ise $(\bar{x}=3,77)$ aritmetik ortalama ile lise alanı Diğer olan öğrenciler katılım sağlamışlardır. Veri toplama aracında yer alan maddelerin, yükseköğretimde kalite göstergesi olduğuna ilișkin katılım sırası, lise alanı Genel $(\overline{\mathrm{x}}=3,80)$, Türkçe Matematik $(\overline{\mathrm{x}}=3,81)$, Sosyal Bilimler ve Fen Bilimleri $(\overline{\mathrm{x}}=3,85)$ şeklinde gerçekleşmiştir.

\section{Öğrencilerin yükseköğretimde kalite göstergelerine ilişkin görüşleri ile bölümü tercih nedenleri arasında anlamlı bir farklılık var mıdır?}

Yükseköğretimde kalite göstergeleri ile ilgili öğrenci görüşlerinin "bölüm tercih nedeni” değişkenine göre anlamlı bir farklılık gösterip göstermediği ile ilgili yapılan varyans analizi sonucu Tablo 9'da sunulmuştur.

Tablo 9 incelendiğinde, öğrencilerin görüşlerinde bölüm tercih nedenlerine göre istatistiksel olarak anlamlı bir farka rastlanmamıştır $\left(\mathrm{F}_{3 ; 805}=1,077, \mathrm{p}>0,05\right)$. Öğrencilerin "bölüm tercih nedeni" değişkenine göre, görüş ortalaması $(\bar{x}=3,83)$ ile $(\bar{x}=3,72)$ arasında değişim göstermektedir. Veri toplama aracında yer alan maddelerin, bölüm tercih nedeni bakımından yükseköğretimde kalite göstergesi olduğunu en çok $(\overline{\mathrm{x}}=3,83)$ aritmetik ortalama ile öğrenciler, "eğitim aldığım alan ile ilgili meslek sahibi olmak için" şeklinde katılım sağlarken, en düşük oranda ise $(\bar{x}=3,72)$ aritmetik ortalama ile "diğer" nedenler şeklinde katılım sağlamışlardır. Veri toplama aracında yer alan maddelerin, öğrencilerin bölümü tercih nedeni bakımından, yükseköğretimde kalite göstergesi olduğuna ilişkin katılım sırası, iş olanağ1 olduğu için $(\bar{x}=3,81)$ ve ailem istediği için $(\bar{x}=3,74)$ şeklinde gerçekleşmiştir. 
Tablo 9

\begin{tabular}{|c|c|c|c|c|c|c|c|c|c|}
\hline $\begin{array}{l}\text { Bölüm Tercih } \\
\text { Nedeni }\end{array}$ & $\mathrm{n}$ & $\begin{array}{l}\text { Ortalama } \\
(\overline{\mathbf{x}})\end{array}$ & $\begin{array}{l}\text { Standart } \\
\text { Sapma(ss) }\end{array}$ & $\begin{array}{l}\text { Varyansın } \\
\text { Kaynağı }\end{array}$ & $\begin{array}{l}\text { Kareler } \\
\text { Toplamı }\end{array}$ & sd & $\begin{array}{l}\text { Kareler } \\
\text { Ortalaması }\end{array}$ & $\mathbf{F}$ & p \\
\hline $\begin{array}{l}\text { Meslek sahibi } \\
\text { olmak için }\end{array}$ & 377 & 3,83 & 0,593 & Gruplar & & & & \multirow{5}{*}{1,077} & \multirow{5}{*}{0,358} \\
\hline İş olanağı olması & 281 & 3,81 & 0,636 & Aras1 & 1,199 & 3 & 0,399 & & \\
\hline $\begin{array}{l}\text { Ailem istediği } \\
\text { için }\end{array}$ & 49 & 3,74 & 0,651 & Grup içi & \multirow{2}{*}{298,922} & \multirow[t]{2}{*}{805} & \multirow[t]{3}{*}{0,371} & & \\
\hline Diğer & 102 & 3,72 & 0,573 & & & & & & \\
\hline Genel & 809 & 3,80 & 0,609 & Toplam & 300,121 & 808 & & & \\
\hline
\end{tabular}

Özetle, araştırma bulgularında görüldüğü gibi, öğrenciler yükseköğretimdeki en önemli kalite göstergelerinin sırasıyla "tesisler, kütüphane ve teknoloji merkezleri”, "yönetim”, "öğretme-öğrenme süreci", "bilimsel ve sosyal etkinlikler", "öğrenciler" ve "öğretim elemanı" olduğunu belirtmişlerdir. Yükseköğretimde kalitenin sağlanabilmesi için bu alt başlıklarda öğrenci görüşlerine dayalı çalışmaların yapılmasına ihtiyaç olduğu görülmektedir.

\section{Tartıșma ve Sonuç}

Öğrenci görüşlerine göre, yükseköğretimde kalite göstergelerinin neler olduğunu belirlemeye yönelik bu araştırmanın sonuçlarına göre, genel liseden mezun olanların aritmetik ortalamalarının yüksek olması ve yüksek oranda katılım sağlamaları, meslek yüksekokullarını tercih eden öğrencilerin çoğunluğunun genel lise mezunu olmaları ile açıklanabilir. YÖK (2019b) verilerine göre, 2019 YKS sonucuna göre, önlisans programlarına yerleşen adayların çoğunluğunun (158,002 kişi) genel lise çıkışlı olması da araştırma sonucunu doğrulamaktadır.

Araştırma sonucuna göre, öğrencilerin yükseköğretimde en önemli gördükleri kalite boyutları sırasıyla, tesisler, kütüphane ve teknoloji merkezleri, yönetim, öğretim süreci, bilimsel ve sosyal etkinlikler, boyutları olduğu; diğerlerine göre daha önemsiz gördükleri boyutların ise "öğrenciler" ve "öğretim elemanı" boyutları olduğu görülmektedir. Bu araştırmada öğrencilerin en önemli gördükleri boyut, "tesisler, kütüphane ve teknoloji merkezleri" iken, araştırma sonuçlarından farklı olarak, Ataman \& Adıgüzel'in (2019) araştırma sonucuna göre, öğrencilerin yükseköğretimde en önemli gördükleri kalite boyutunun "yönetim", diğer kalite boyutları ise, "fizikî alt yapı ve tesisler", "öğretme ögrenme süreci" ile "bilimsel ve sosyal etkinlikler"dir.

Araştırma sonuçları ile benzer şekilde, Ataman \& Adıüzel'in (2019) araştırma sonucuna göre, "ögrenciler" ve "öğretim elemanı" boyutları, yükseköğretimde daha az önemli kalite göstergeleri olarak sıralanmıştır. Burgaz \& Ekinci'nin (2007) araştırma sonucuna göre, öğrencilerin üniversitenin sunduğu tüm hizmetlere yönelik beklentilerinin yüksek, memnuniyet düzeylerinin ise düşük olduğu belirlenmiştir. Kurklareli Üniversitesi'nin (2020) araştırma sonucunda da, öğrencilerin üniversitenin sunmuş olduğu tüm hizmetlere yönelik beklentilerinin daha yüksek olmasına rağmen, bu beklentilerinin tam olarak karşılanamadığı ve memnuniyet düzeylerinin daha düşük olduğu görülmektedir. Araştırma sonucu, yükseköğretimde kalite bakımından fiziksel ve teknolojik altyapının uygunluğunun sağlanmasının önemli olduğunu göstermektedir. $\mathrm{Bu}$ sonuçlara göre, yükseköğretimde kalite için öncelikle öğrenci memnuniyetinin karşılanması gerektiği belirtilebilir.

Araştırma sonucuna göre, öğrenciler öncelikle meslekî sahibi olmak ve öğrenim görecekleri bölüm iş olanağ1 sağladığ̣ için bölüm tercihinde bulunmuşlardır. Bu sonuç, öğrencilerin bölüm tercihlerinde mesleğin özellikleri ile bölümün istihdam olanağının etkili olduğu söylenebilir. Bölüm tercihlerinde ailelerin isteklerinin çok etkili olmaması, öğrencilerin bölüm tercihlerini bilinçli olarak ve istedikleri bölüme, programa uygun yaptıkları söylenebilir.

Araştırma sonucuna göre, katılımcılar "öğrenciler" boyutuna ilişkin en önemli kalite göstergesinin "engelli ögrencilere sunulan eğitim hizmetlerinin yeterliliği" olduğunu, en önemsiz görülen kalite göstergesinin ise "üniversitenin öğrenci saylsının fazla olması" olduğunu belirtmişlerdir. Bu sonuç, Meraler'in (2011) araştırma sonuçları ile desteklenmektedir. Ayrıca, Ataman \& Adıgüzel'in (2019) araştırma sonuçlarında da, benzer sonuçlara ulaşılmıştır. Meslek yüksekokulu öğrencilerinin yükseköğretimde kalite bakımından üniversiteye kayıtlı öğrenci sayısının önemli bir faktör olmadığını 
belirtmeleri, öğrencilerin nicelikten çok niteliğin önemli olduğuna inandıkları şeklinde açıklanabilir. Katılımcıların yükseköğretimde "öğrenciler" boyutu altında, yeterli düzeydeki diğer kalite göstergeleri olarak sırasıyla, öğrencilerin üniversiteden memnuniyeti, öğrencilerin üniversiteye giriş puanlarının yüksek olması, önlisans mezunu öğrencilerin lisans programlarına kabul edilme oranları, öğrencilerin mezuniyet notunun yüksek olması, mezun öğrencilerin iş bulma olanağı, olarak sıralanmıştır. Araştırmaya katılan öğrenciler, üniversiteden mezun olan öğrenci sayısının fazla olması ile öğrencilerin mezun oldukları lise türünü, orta düzeyde bir kalite göstergesi olarak belirtmişlerdir.

Araştırma sonucuna göre, öğrenciler "ögrretim elemanı" boyutuna ilişkin olarak en önemli buldukları kalite göstergesinin "ögrretim elemanlarının ögrencileri önemsemesi" olduğunu; en önemsiz görülen kalite göstergesinin ise "yabancı ögretim elemanlarının sayısı" olduğunu belirtmişlerdir. Bu sonuç, Meraler'in (2011) araştırma sonuçları ile desteklenmektedir. Ataman \& Adıgüzel'in (2019) araştırma sonuçlarına benzer şekilde, "öğretim elemanlarının öğrencileri önemsemesi" önemli bir kalite göstergesi olarak belirtilirken, "yabancı öğretim elemanlarının sayısı" yükseköğretimde kaliteyi etkileyen önemli bir gösterge olarak görülmemektedir. Cevher'in (2015) araştırma sonucuna göre, öğrenciler hizmet kalitesi bakımından meslek yüksekokullarındaki akademik personelin yeterliliği ve tutumunu olumlu olarak değerlendirmişlerdir.

Öğrencilere göre, yükseköğretimde öğretim elemanları ile ilgili diğer kalite göstergeleri olarak sırasıyla, öğretim elemanlarının öğrenci başarılarını desteklemesi, öğretim elemanlarının öğrencilerce yeterli görülmesi, öğretim elemanlarının sayısal yeterliliği, öğretim elemanlarının yurt dışı deneyimi, öğretim elemanlarının yayın sayıları, öğretim elemanı başına düşen öğrenci sayısı şeklinde belirtilmiştir. Öğrenciler, öğretim elemanı ile ilgili faktörleri yeterli düzeyde kalite göstergesi olarak değerlendirmişlerdir. YÖK (2019a) verilerine göre, yükseköğretimde öğretim kadrosu meslekî yönden geliştirilmeli ve öğretim becerileri iyileştirilmelidir. Ayrıca, öğretim elemanlarının öğretme-öğrenme sürecinde öğrenciyi merkeze alan değerlendirme yaklaşımları konusunda yetiştirilmesi gerektiği vurgulanmaktadır. Yavuz \& Gülmez'e (2016) göre, üniversitelerde hizmet kalitesinin arttırllabilmesi için öğrenci sayısı ile öğretim elemanı sayısı arasında bir denge olmalıdır. Can'ın (2020) araştırma sonucuna göre ise, yükseköğretimde öğretim elemanlarının yeterlikleri arttırılmalı, öğrenci ile sağlıklı iletişim kurmaları sağlanmalı ve derslerde farklı yöntem ve teknikleri kullanmaları özendirilmelidir. Bu sonuçlar, öğretim elemanlarının nicelik ve niteliğinin yükseköğretimde kalite bakımından önemli bir unsur olduğunu ortaya koymaktadır. Araştırma sonucunda, öğretim elemanlarının yayın sayılarının önemli bir kalite göstergesi olarak belirtilmesi, URAP'ın (2019), dünya üniversite sıralamalarında bilimsel yayınların sayısı ve niteliğinin gösterge olarak esas alınması ile doğrulanmakta ve desteklenmektedir.

Araştırma sonucuna göre, öğrenciler "öğretme-öğrenme süreci" boyutuna ilişkin en önemli buldukları kalite göstergelerinin "ögrretim sürecinde yeni ögrretim teknolojilerinin kullanımı" ile "öğretim elemanlarının ögrenciler ile aralarındaki etkili iletişim" olduğunu belirtmişlerdir. En önemsiz görülen kalite göstergesinin ise "öğrenci başarısını değerlendirmedeki yaklaşımların çağdaş eğitim anlayışına uygun olması" olarak belirtilmiştir. Öğretim elemanlarının öğrencilerle etkili iletişim kurabilmeleri ve bunu sürdürebilmeleri için çalışma ortamlarının uygun olması, kendilerini mutlu hissetmeleri ve işlerini severek yapmalarının önemli olduğu söylenebilir. Ancak, Karadağ ve Yücel'in (2020, s.8) araştırma sonucuna göre, Türkiye'de akademisyenler kendilerini orta seviyede akademik özgür olarak görmekteler, üniversitelerin yönetiminden memnun değiller, yoğun şekilde tükenmişlik hissi ve mutsuzluk yaşamaktalar, üniversitelerine aitlik ve bağlilık hissi beslememektedirler. Ayrıca, üniversitelerde akademik kültür ve desteğin düşük olduğu, buna karşın akademisyenlerin yönetimin siyasî angajmanından rahatsızlık duydukları belirtilmektedir. Bu sonuçlara göre, öğretim elamanların olumsuz çalışma koşulları ile buna yönelik algılamalarının, öğrencilerle etkili iletişim kurmalarında büyük engeller oluşturabileceği, bunun da öğretimim kalitesine olumsuz yansiyabileceği belirtilebilir. $\mathrm{Bu}$ yüzden, araştırma sonucunda "ögretim elemanlarının ögrenciler ile aralarındaki etkili iletişsim" kurmalarının yükseköğretimde önemli kalite göstergeleri arasında belirtilmesi, öncelikle öğretim elamanların memnuniyetlerinin sağlanması ve uygun çalışma koşullarına kavuş̧urulmaları gerektiğini de göstermektedir. Araştırma sonuçları ile benzer şekilde, Meraler'in (2011) araştırma sonucuna göre de öğrenciler, "öğretme-öğrenme sürecinde yeni öğretim teknolojilerinin kullanılması" durumunu yükseköğretimde en önemli kalite göstergelerinden biri olarak belirtmişlerdir. Öğrenciler, "öğretmeögrenme süreci" alt boyutunda yer alan tüm maddeleri yeterli düzeyde kalite göstergesi olarak değerlendirmişlerdir. Bu sonuç, öğrencilerin öğretme-öğrenme sürecini yükseköğretimde kalite 
bakımından önemsediklerini göstermektedir. Yükseköğretimde kalitenin sağlanabilmesi için öncelikle öğretimin kalitesinin sağlanması gerekmektedir. Ancak, Karadağ ve Yücel'in (2020) araştırma sonucuna göre, Türkiye'de yükseköğretimde öğretimin kalitesi düşüktür. Bu sonuç, Türkiye'de yükseköğretimde kalitenin sağlanabilmesi için öncelikle öğretimin kalitesinin artırılması gerektiğini göstermektedir. Demirhan-Yüksel'e (2011) göre, eğitim-öğretim alanında yapılması gerekenler, kaliteli bir üniversite için önem taşımaktadır. YÖK'e (2019a) göre, yükseköğretim kurumları sınıfta ve sınıf dışındaki öğrenme ortamlarını öğrenciyi merkeze alacak şekilde daha etkileşimli bir yapıda planlamalı ve buna yönelik düzenlemeleri hayata geçirmelidir. Araştırma sonuçlarını destekler nitelikte, Can'ın (2020) araştırma sonucuna göre ise, öğrenciler yükseköğretimdeki öğretim sürecinde daha fazla uygulamalı eğitim yapılmasını, öğrenci başarısının alternatif yöntemlerle değerlendirilmesini ve çağdaş öğretim yöntemlerinin kullanılmasını istemektedir.

Araştırma sonuçlarına göre, öğrenciler "tesisler, kütüphane ve teknoloji merkezleri" ile ilgili en önemli kalite göstergesinin "derslikler, atölyeler ve laboratuvarlar gibi öğretim alanlarının yeterliği ve bakımlı olması" olduğunu belirtmişlerdir. En önemsiz görülen kalite göstergesi olarak "üniversitenin akademik birimleri ile programlarının niceliği" belirtilmektedir. Meraler' in (2011) araştırma sonuçlarında ise, eğitim fakültesi ögrencileri "tesisler, kütüphane ve teknoloji merkezleri" boyutunda en önemli kalite göstergesini "üniversitenin kütüphanesinde zengin basılı ve elektronik kaynakların yer alması" olarak belirtmişlerdir. $\mathrm{Bu}$ sonuç, eğitim fakültesi öğrencileri ile meslek yüksekokulu öğrencilerinin görüşlerinin farklılaştığını ve meslek yüksekokulu öğrencilerinin önceliğinin "derslikler, atölyeler ve laboratuvarlar gibi ögretim alanlarının yeterliği ve bakımlı olması" olduğu ve bu konuda sorunlarla karşılaştıkları ve önemli beklentileri bulunduğu şeklinde yorumlanabilir. Ataman \& Adıgüzel'in (2019) araştırma sonucuna göre, derslikler, laboratuvarlar, sosyal ve sportif amaçlı yapılar ile ders araç ve gereçleri gibi üniversitelerdeki fiziksel alt yapı ve tesisler, yükseköğretimde kalite bakımından önem taşımaktadır. Çünkü, Gencel'e (2001) göre, yükseköğretim kurumlarının çoğunluğu zor koşullar altında eğitim vermektedir. Kaynak yetersizliğine bağlı olarak, sınıflar kalabalık, kütüphane ve laboratuvarlar yetersizdir. Cevher'in (2015) araştırma sonucuna göre, meslek yüksekokulu öğrencileri donanım, tesisler, derslikler, sosyal mekânlar ve fiziksel alanın yetersiz olduğunu belirtmişlerdir. Bu sonuçta, derslik, atölye, laboratuvar gibi fiziksel olanakların yükseköğretimde kalite bakımından önemli bir faktör olduğunu doğrulamaktadır. Kırklareli Üniversitesi'nin (2020) araştırma sonucuna göre ise, meslek yüksekokulu öğrencileri kütüphane kaynakları ile destek hizmetlerini yetersiz bulmuşlardır. YÖK (2019a) verilerine göre, yükseköğretim kurumlarında sınıflar, laboratuvarlar, kütüphaneler gibi fiziksel altyapı olanakları ile ders kitapları ve danışmanlık hizmetleri ile öğrenme desteği, gerekli nitelik ve nicelikte olmalı, tüm öğrencilerin erişebileceği şekilde sunulmalıdır. Ayrıca, engelsiz üniversite uygulamaları kapsamında sunulması gereken bu hizmetler sürekli izlenerek değerlendirilmelidir. Özer, Gür \& Küçükcan'a (2010) göre, yükseköğretim kurumlarındaki beşerî ve fiziksel altyapının güçlendirilmesi, yükseköğretimdeki kalite uygulamalarına doğrudan olumlu katkı sağlayacaktır. $\mathrm{Bu}$ yüzden, öncelikli olarak üniversitelerdeki insan kaynağı ihtiyacı karşılanmalı ve fiziksel donanımlar tamamlanmalıdır. Can'ın (2020) araştırma sonuçlarına göre de, öğrenciler yükseköğretimde fiziksel ve teknolojik olarak derslik, araç-gereç, internet altyapısı, kütüphane ve laboratuvarların geliştirilmesini istemektedir. Bu sonuç, araştırma sonuçlarını doğrulamakta ve desteklemektedir.

Yavuz \& Gülmez'e (2016) göre, üniversitelerin hizmet kalitesinin arttırılabilmesi için fiziksel yönden geliştirilmeleri gerekmektedir. Saydan'a (2008, s.44-46) göre, öğrencilerin yükseköğretimde kalite beklentisi gün geçtikçe artmakta, sosyal, kültürel ve sportif etkinlikler ile fizikî alanların yeterliliğine yönelik önemli talepleri bulunmaktadır. Öğrenciler üniversitedeki tesis, kütüphane ve teknoloji merkezlerinin kalite göstergesi olduğuna yüksek oranda katılmaktadır. Yani, öğrenciler tesisler, kütüphane ve teknoloji merkezleri boyutunda yer alan tüm maddeleri yeterli düzeyde kalite göstergesi olarak değerlendirmişlerdir.

Araştırma sonucunda, öğrenciler "yönetim" boyutuna ilişkin en önemli kalite göstergesi olarak "yönetimin ögrenci sorunlarını ciddiye alması" olarak belirtmişlerdir. Ayrıca, "üniversitenin karar verme sürecinde öğrencilerin görüşlerini dikkate alması", "üniversitede demokratik bir ortamın olması" ve "yönetimin personel ile olumlu ilişkiler içinde olması" da kalitenin bir göstergesi olarak değerlendirilmiştir. Araştırma sonuçları ile benzer şekilde, Meraler’in (2011) araştırma sonucuna göre, öğrenciler yönetim boyutunda en önemli kalite göstergesi olarak, "üniversitedeki ortamın demokratiklĭğ i" ile "yönetimin öğrenci sorunlarını ciddiye almasını" belirtmişlerdir. Araştırma sonuçlarını doğrular ve destekler nitelikte, Kırklareli Üniversitesi’nin (2020) araştırma sonucuna göre, 
meslek yüksekokulu öğrencileri, üniversitede her kademedeki yöneticilerin öğrencilerin sorunları hakkında yeterli düzeyde bilgilenmesini ve sorun çözmeye istekli olmasını, bu konularda öğrenciler ile görüşmeler ve toplantılar yapılmasını istemektedir. Öğrenciler, karşılaştıkları sorunların üst yöneticilere ulaşmadığını veya sorunlara yönelik yeterli düzeyde çözüm üretilemediğini, etkili geribildirim sağlanamadığını düşünüyor olabilirler. Bu sonuçlar, üniversite yönetiminin öğrencilerin sorunlarını daha çok önemsemelerini, öğrenci görüşlerine daha çok önem vermelerini ve sorunların çözümüne yönelik öğrencilere etkili geribildirim sağlanması gerektiğini göstermektedir. Yavuz \& Gülmez'e (2016) göre, üniversitelerde hizmet kalitesinin arttırılabilmesi için öğrenci görüşleri alınmalı, önemsenmeli ve sunulan hizmetin değerlendirmesi yapılmalıdır. YÖK (2019a) verilerine göre, 2017-2018 yıllarında yükseköğretim kurumlarının yaptığı öz değerlendirmeye göre "öğrenciyi merkeze alan öğrenmeögretme ve değerlendirme" ölçütünde herhangi bir ilerleme olmamış ve bu alanlarda gerileme olduğu ortaya çıkmıştır. $\mathrm{Bu}$ sonuç, yükseköğretim kurumlarında öğrenci merkezli uygulamaların yaygınlaştırılması ihtiyacı olduğunu göstermekte ve araştırma sonuçlarını doğrulamaktadır.

Araştırmada, diğer maddelere göre, daha düşük düzeyde değerlendirilen kalite göstergesinin ise "üniversite çalışanlarının yönetimden memnun olmaları" olduğu görülmektedir. Benzer sonuç, Meraler'in (2011) araştırma sonucunda da ortaya çıkmıştır. Görüldüğü gibi, araştırmaya katılan öğrenciler "yönetim" alt boyutunda yer alan maddelerin kalite göstergesi olduğunu "oldukça katılıyorum" şeklinde görüş belirterek yönetim alt boyutunda yer alan tüm maddeleri yeterli düzeyde kalite göstergesi olarak değerlendirmişlerdir.

Araştırma sonucuna göre, öğrenciler "bilimsel ve sosyal etkinlikler" boyutundaki en önemli kalite göstergesinin "üniversitenin dünyadaki en iyi üniversiteler arasında yer alması" olduğunu belirtmişlerdir. Araştırma sonuçlarını destekler nitelikte Meraler'in (2011) araştırma sonucuna göre de, "üniversitenin dünyadaki en iyi üniversiteler sıralamasında olması" öğrencilere göre yükseköğretimde kalitenin göstergesidir. URAP (2019) raporuna göre, 2019-2020 üniversitelerin dünya sıralamaları incelendiğinde, dünyanın ilk 2500 üniversitesi arasına Türkiye'den 82 üniversite girebilmiştir. Bilimsel yayınların sayısı ve kalitesine bağlı uzun süreli akademik üretkenliğin ölçüldüğü bu sıralama, Türkiye'de yükseköğretimde kalite göstergeleri bakımından "bilimsel üretkenliği” ve "akademik ürünlerin kalitesinin" öncelikli ele alınması gerektiğini göstermektedir. Böylece, daha fazla üniversitenin yükseköğretimde kalite göstergesi olarak "dünyadaki en iyi üniversiteler arasında yer alacağını" söyleyebiliriz.

Araştırmada en önemsiz görülen kalite göstergesi ise "üniversitenin kuruluş tarihinin eski olması" olarak belirtilmiştir. Araştırma sonucuna göre, öğrenciler "bilimsel ve sosyal etkinlikler" alt boyutu altında yükseköğretimdeki diğer önemli kalite göstergeleri olarak sırasıyla, üniversitenin değişik alanlarda aldığı ödül sayıları, bilimsel yönlerden topluma katkı sunması, öğrencilere sunulan danışmanlık hizmetleri ile üniversitenin öğrencilere sunmuş olduğu sosyo-kültürel olanakların yeterliğini belirtmişlerdir. Ayrıca, üniversitenin yürütmüş olduğu uluslararası araştırmalar ve projelerin fazla olması, tören ve sosyal etkinliklerin başarısı ile uluslararası öğrenci değişim programlarına katılımın yüksekliği kalite göstergeleri olarak sıralanmıştır. Görüldüğü gibi, araştırma sonucuna göre en önemli kalite göstergesi olarak, üniversitenin dünyadaki en iyi üniversiteleri arasında bulunmasının belirtilmesi uluslararasılaşmanın kalite bakımından önemli olduğunu ortaya koymaktadır. Uluslararasılaşma, YÖKAK'ın (2020) yükseköğretim kurumlarının dış değerlendirmesinde esas aldığı ölçütler arasında yer almaktadır. Üniversitelerin uluslararasılaşmasında Erasmus gibi değişim programları, öğrenim gören yabancı öğrenci sayısı, uluslararası akademik personel, uluslararası projeler, yayınlar, organizasyonlar, ağlar, eğitim programının uluslararası programlarla uyumu ve ortak diploma programlarının varlığı büyük önem taşımaktadır. URAP (2019) raporunda belirtildiği gibi, üniversitelerin uluslararasılaşması en önemli saygınlık ölçütü olup, bunun için uluslararası iş birliğine ihtiyaç bulunmaktadır.

Araştırma sonuçlarını destekler nitelikte, Kırklareli Üniversitesi (2020) tarafından yürütülen araştırma sonucuna göre, meslek yüksekokulu öğrencileri üniversite içinde öğrencilerin katılabileceği çeşitli sosyal, kültürel ve sportif etkinlikler ile öğrencilere yönelik yeterli sayıda ve nitelikte kulüp, spor ve sanat etkinlikleri düzenlenmesini istemektedirler. YÖK (2019a), üniversitelerde öğrenci toplulukları tarafından yürütülmekte olan sosyo-kültürel ve sportif faaliyetler ile etkinlikler için gerekli olan fiziksel, maddî ve danışmanlık desteğinin sağlanması gerektiğini belirtmektedir. Ayrıca, sosyal, kültürel ve sportif faaliyet ve etkinliklerin yürütülmesi ve yönetilmesine yönelik daha etkili bir idarî örgütlenmenin kurulması ve işletilmesi gerektiği belirtilmektedir. Can'a (2020) göre, yükseköğretimde daha fazla 
bilimsel, sosyal, kültürel etkinliklere, ders dışı uygulamalara önem verilmeli, farklı kurumlarla iş birliği yapılmalıdır. Alkan, Suiçmez, Aydınkal \& Şahin'e (2014) göre, yükseköğretimde öğrencilere yönelik sosyal, sportif ve kültürel etkinlikler ile birlikte yurt dışı değişim programları, sempozyumlar, fuarlar ve teknik gezilere katılım olanağı sağlanmalıdır. Çünkü, Köksal'ın (2015) araştırma sonuçlarına göre, üniversitenin sosyal olanakları ile öğrenci memnuniyeti arasında önemli derecede bir ilişki bulunmaktadır.

Araştırma sonucuna göre, öğrencilerin kalite ile ilgili görüşleri, cinsiyete, öğrenim gördükleri sınıfa, mezun oldukları lise türüne, lisedeki alan ve bölüm tercihlerine göre farklılaşmamaktadır. Bu sonuçlara göre, meslek yüksekokulu öğrencilerinin demografik özellikleri yükseköğretimde kalite göstergelerine ilişkin görüşlerini etkileyen bir faktör değildir. Araştırma sonuçlarını destekler nitelikte, öğrencilerin yükseköğretimde kaliteye yönelik görüşlerinin; sınıf, mezun olunan lise, fakülte ve öğretim türü değişkenleri (Ataman \& Adıgüzel, 2019), cinsiyet (Yavuz \& Gülmez, 2016), bölümü tercih nedeni (Meraler, 2011), öğrenim gördüğü sınıf (Karakaya, Kılıç \& Uçar, 2016) bakımından farklılığa neden olmadığı şeklinde araştırma sonuçları bulunmaktadır.

Ancak, araştırma sonuçlarından farklı olarak değişik araştırma sonuçlarına göre öğrencilerin yükseköğretimde kalite ile ilgili görüşleri, cinsiyete (Karakaya, Kılıç \& Uçar, 2016), öğrenim gördükleri fakülteye (Özdemir, 2015), cinsiyet, öğrenim görülen program ve sınıf düzeyine (Hacıfazlığlu, 2006), fakültelere ve üniversitelerin kuruluş yılları ile fiziksel olanaklara (Yavuz \& Gülmez, 2016) göre farklılaşmaktadır. Ayrıca, Meraler'in (2011) araştırma sonucuna göre, öğrencilerin kalite ile ilgili görüşleri mezun oldukları lise, lisedeki alan, üniversitede öğrenim gördüğü bölüm ve öğrenim gördüğü sınıf düzeyine göre anlamlı farklılık göstermektedir. Burgaz \& Ekinci'nin (2007), araştırma sonucuna göre, öğrencilerin üniversitenin tüm hizmetlerine yönelik görüşleri cinsiyete, öğrenim görülen fakülteye göre farklılaşmakta, beklenti düzeyi bakımından ise cinsiyete göre bir farklılık bulunmaktadır. Örneğin, kız öğrencilerin beklenti düzeyinin daha yüksek olduğu belirlenmiştir. Ancak, memnuniyet düzeyi bakımından cinsiyete göre bir farklılık bulunmamaktadır. Yani beklentiler farklı, ancak memnuniyetler benzerdir.

Araştırma sonucuna göre, aritmetik ortalamaların 2.sınıf öğrencilerinde daha yüksek olması, veri toplama aracında yer alan maddelerin yükseköğretimde kalite göstergeleri olduğuna, 2.sınıf öğrencilerinin 1. sınıf öğrencilerine göre daha çok katılım sağladıklarını göstermektedir. Bu sonuç, 2.sınıf öğrencilerinin daha tecrübeli oldukları, sistemi daha iyi bildikleri, üniversiteyi ve olanaklarını daha iyi tanıdıkları vb. faktörlerle açıklanabilir. Ayrıca, lise alanı Yabancı Dil olan öğrencilerin ölçek maddelerinin yükseköğretimde kalitenin göstergesi olduğuna yüksek oranda katılım göstermesi, yabanc1 dil farkındalığının kalite faktörlerini değerlendirmede etkili olduğu söylenebilir.

Karaboğa'nın (2018) belirttiği gibi, yükseköğretimde kalite için yönetimsel, vizyonel, operasyonel, süreçsel ve insan bazlı engeller en aza indirilerek motive edici bir süreç takip ve yönlendirme sistemine ihtiyaç bulunmaktadır. Ayrıca, yükseköğretim kurumlarının kaynakları (malî, fizikî ve insan kaynağı), ülke politika ve stratejilerine uygun bir şekilde organize edilmelidir.

Araştırma sonucuna göre, yükseköğretimde kalitenin geliştirilebilmesi için tesisler, kütüphane ve teknoloji merkezleri, yönetim, öğretme-öğrenme süreci, bilimsel ve sosyal etkinlikler, öğrenciler ile öğretim elemanı boyutunda kalite odaklı politikaların izlenmesine ihtiyaç bulunmaktadır. Çünkü, öğrencilerin bu alanlarda önemli ihtiyaç ve beklentileri bulunmaktadır. Ayrıca, öğrencilerin bölüm tercihlerini bilinçli olarak meslek sahibi olmak ve iş olanağı nedeniyle tercih etmeleri, yükseköğretimde hem kalite odaklı hem de istihdam odaklı politikalara ihtiyaç olduğunu göstermektedir. Bu bağlamda, özellikle meslek yüksekokullarının fiziksel olanaklarının geliştirilmesi ve öğretme-öğrenme sürecinin etkinliğini artırmaya yönelik politikalar ile öğrenci, ilgi, beklenti, memnuniyet ve taleplerini merkeze alan yaklaşımların izlenmesine ihtiyaç olduğu görülmektedir.

\section{Öneriler}

Araştırma sonuçlarına göre, öğrencilerin önemsedikleri kalite göstergeleri dikkate alındığında, genel olarak yükseköğretimde, özel olarak ise meslek yüksekokullarında daha kaliteli bir eğitim için üniversite yönetimleri ile politika yapıcılarına yönelik aşağıdaki öneriler sunulabilir.

1.Üniversitelerin dünyanın iyi üniversiteleri sıralamasında yer alabilmesi için nicelikten çok niteliği esas alan politikalara ağırlık verilmelidir.

2.Üniversitelerdeki derslikler, atölyeler ve laboratuvar gibi alanların yeterli nicelik ve nitelikte olmasına dikkat edilmelidir. 
3.Üniversitelerin tüm birimleri başta olmak üzere, özellikle de meslek yüksekokullarında fiziksel alt yapıları geliştirmeli ve yeterli düzeyde yatırım yapılmalıdır.

4.Üniversitelerin kütüphaneleri basılı ve elektronik kaynaklarla zenginleştirilmeli, öğrencilerin eğitim olanaklarına uzaktan eğitim yöntemleri ile erişimi sağlanmalıdır.

5.Üniversite yönetimleri katılımcı bir yönetim anlayışını esas almalı, öğrenci görüşlerine önem verilmelidir.

6. Araştırma sonucunda, "engelli öğrencilere sunulan eğitim hizmetlerinin yeterliliği” önemli bir kalite göstergesi olduğu için, üniversite yönetimleri eğitim hizmetlerinin sunumunda engelli öğrencilerin ilgi, ihtiyaç ve beklentilerini dikkate almalıdır.

7.Üniversitelerin çeşitli alanlarda sahip olduğu ödül sayısı kalite göstergesi olduğu için sosyal, kültürel ve eğitsel alanlarda daha fazla faaliyet göstermeleri sağlanmalı ve bu faaliyetlere öğrenci katılımı sağlanmalıdır.

8.Öğretme-öğrenme süreçlerinde yeni öğretim teknolojilerinin kullanılması konusunda öğretim elemanlarına gerekli eğitimler verilmeli, öğretim elemanı yetiştirme ve istihdamında bu konuya önem verilmelidir.

9.Öğretim elemanlarının öğrenciler ile yeterli düzeyde etkili bir iletişim sağlamaları için gerekli koşullar sağlanmalı, zorunlu ders yükleri azaltılmalıdır.

10. Öğretim elemanlarının çalışma koşulları ve özlük hakları iyileştirilmelidir.

11.Üniversitelerde demokratik bir ortam için gerekli koşullar sağlanmalı, öğretim elemanı, öğrenci ve personelin görüşlerine önem verilmelidir.

12.Üniversitelerin öğretim hizmeti dışında bilimsel araştırmalarla topluma katkı sağlaması sağlanmalıdır. Bu amaçla öğrencilerin katılımı ile sosyal sorumluluk projeleri geliştirilebilir.

13.Üniversitelerin tüm birimlerinde öğrencilere yönelik yüz yüze ve e-rehberlik ve danışmanlık hizmetleri sunulmalıdır.

\section{Kaynakça}

Aktan, C.C., \& Gencel, U. (2007). Yükseköğretimde akreditasyon. Değişim çağında yükseköğretim içinde. İzmir: Yaşar Üniversitesi Yayını.

Alkan, R. M., Suiçmez, M., Aydınkal, M., \& Şahin, M. (2014). Meslek yüksekokullarındaki mevcut durum: Sorunlar ve bazı çözüm önerileri. Yükseköğretim ve Bilim Dergisi, 4(3), 133-140.

Arslan, H. (2002). Quantity versus quality in Turkish Higher Education. Paper presented at The 21st Century The Balkans Scientific Conference, 1-3 November. https://eric.ed.gov/?id=ED477531, adresinden 12.02.2019 tarihinde alınmıştır.

Ataman, O., \& Adıgüzel, A. (2019). Yükseköğretimde kalite algısı: Düzce Üniversitesi örneği. Elektronik Eğitim Bilimleri Dergisi, 8(15), 53-70.

Balcı, A. (2004). Sosyal bilimlerde araştırma, yöntem, teknik ve ilkeler. Ankara: Pegem Yayıncılık.

Burgaz, B., \& Ekinci, C.E. (2007). Öğrencilerin Hacettepe Üniversitesi’nce sunulan hizmetlere ilişkin beklenti ve memnuniyet düzeyleri. Hacettepe Üniversitesi İktisadî ve İdarî Bilimler Fakültesi Dergisi, 25(1), 71-89.

Can, E. (2020). Yükseköğretimde kalite için meslek yüksekokulu öğrencilerinin görüşleri. Anemon Muş Alparslan Üniversitesi Sosyal Bilimler Dergisi, 8(3), 699-710.

Cevher, E. (2015). Yükseköğretimde hizmet kalitesi ve kalite algısının belirlenmesine yönelik bir araştırma. Uluslararası Sosyal Araştırmalar Dergisi, 8(39), 804-814.

Demirhan-Yüksel, Y. (2011). Kalite ve kaliteli üniversite kavramlarına ilişkin üniversite öğrencilerinin algıları (Gazi Üniversitesi- Gazi Eğitim Fakültesi Örneği). (Yayımlanmamış yüksek lisans tezi). Gazi Üniversitesi Eğitim Bilimleri Enstitüsü. Ankara.

Deveci, N. K. (2012). Türk yükseköğretiminde eğitim-öğretim hizmetlerinin kalite düzeyinin ve kalite yükseltme çalışmalarının incelenmesi: Türkiye'deki devlet ve vakıf üniversiteleri üzerinde bir saha çalışması. (Yayımlanmamış yüksek lisans tezi). Atatürk Üniversitesi. Erzurum.

Elmacı, O., Poyraz, K., \& Çalık, M. (1999). Yükseköğretimde (meslek yüksekokullarında) kalite güvence sisteminin oluşturulmasına yönelik bir değerlendirme format önerisi. Dumlupınar Üniversitesi Sosyal Bilimler Dergisi, 1,111-137.

Gencel, U. (2001). Yükseköğretim hizmetlerinde toplam kalite yönetimi ve akreditasyon. Dokuz Eylül Üniversitesi Sosyal Bilimler Enstitüsü Dergisi, 3(3), 164-218. 
Giroux, H.A. (2014). Ĕgitimde kuram ve direniş. (S. Demiralp, Çev.). Ankara: Dost Kitabevi Yayınları.

Güney, A. (2019). Kalite yönetimi sürecinde yükseköğretimde akreditasyon süreci. Turkish Studies, $14(2), 401-412$.

Hacıfazlığlu, Ö. (2006). Avrupa Birliği yükseköğretim kalite göstergeleri ve Türkiye örneği. (Yayımlanmamış doktora tezi). Marmara Üniversitesi Eğitim Bilimleri Enstitüsü. İstanbul.

Hamutoğlu, N. B., Ünveren-Bilgiç, E. N., \& Elmas, M. (2020). Yükseköğretimde kalite süreçleri: İnsani gelişme endeksi raporlarına göre ülkelerin karşılaştırmalı olarak incelenmesi. Yükseköğretim Dergisi, doi:10.2399/yod.19.521343.

Hill, D. (2016). Eleştirel eğitim ve Marksizm. (N. Korkmaz, Çev.). İstanbul: Kalkedon Yayıncılık.

Karaboğa, K. (2018). Yükseköğretimde kalite çalışmalarına sistemsel arayışlar. İstanbul: SETA Yayınları.

Karadağ, E., \& Yücel, C. (2020). Akademik ekoloji: Akademisyenlerin gözünden üniversiteler 2020. Üniar Yayınları. https://www.uniar.net/ekoloji, adresinden 11.10.2020 tarihinde alınmıştır.

Karakaya, A., Kılıç, İ., \& Uçar, M. (2016). Üniversite öğrencilerinin öğretim kalitesi algısı üzerine bir araştırma. Karabük Üniversitesi Sosyal Bilimler Enstitüsü Dergisi, Özel Sayı 2, 40-55.

Karasar, N. (2019). Bilimsel araştırma yöntemi: Kavramlar, ilkeler, teknikler. (34.basım). Ankara: Nobel Yayınları.

Kırklareli Üniversitesi. (2020). 2019 ögrenci memnuniyet araştırması. Kırklareli: Kırklareli Üniversitesi Basımevi.

Köksal, O. (2015). Yaşam kalitesi ve yaşam doyumu: Üniversite öğrencileri üzerine bir araştırma. S.Doğan (Ed.).Yaşam doyumu: Seçme konular içinde (s.23-37). Ankara: Nobel Yayınları.

Meraler, S. (2011). Eğitim fakültesi ögrencilerinin yükseköğretimde kaliteye ilişskin görüşlerinin belirlenmesi. (Yayımlanmamış yüksek lisans tezi). Harran Üniversitesi Sosyal Bilimler Enstitüsü. Şanlıurfa.

Owlia, M., \& Aspinwall, E. (1996). A framework for the dimensions of quality in higher education. Quality Assurance in Education. 4(2), 12-20.

Özdemir, M. (2015). Yükseköğretim kalite göstergeleri üzerine bir inceleme (Gaziantep Üniversitesi Örneği). Uluslararası Eğitim Bilimleri Dergisi, 2(3), 191-207.

Özer, M., Gür, B. S., \& Küçükcan, T. (2010). Yükseköğretimde kalite güvencesi. Ankara: SETA Yayınları.

Rehber, E. (2007). Dünyada değişen yükseköğretim ve kalite anlayışı. Değişim çăğıda yükseköğretim içinde. İzmir: Yaşar Üniversitesi Yayını.

Saydan, R. (2008). Üniversite öğrencilerinin öğretim elemanlarından beklentileri. Yüzüncü Yıl Üniversitesi İ̈BF örneği. Gazi Üniversitesi İ̈BF Dergisi, 10(1), 63-79.

Sayılan, F. (2007). Küreselleşme ve eğitim. Ebru Oğuz ve Ayfer Yakar (Ed.). Küreselleşme ve eğitimdeki değişim, içinde (s.59-82). Ankara: Dipnot Yayınları.

Stukalina, Y. (2010). Using quality management procedures in education: Managing the learnercentered educational environment. Technological and Economic Development of Economy, 16(1), 75-93.

Şimşek, H., İslim, Ö. F., \& Öztürk, N. (2019). Yükseköğretimde kalite arayışında bir gösterge olarak öğrenci memnuniyeti: Bir ölçek geliştirme çalışması. Trakya Eğitim Dergisi, 9(3), 380-395.

Tezcan, M. (2017). Eğitim sosyolojisi. Ankara: Anı Yayıncılık.

URAP.(2019). 2019-2020 URAP Dünya siralamast basin bildirisi. http://tr.urapcenter.org/2019/2019-2020-URAP-Dunya-Siralamasi-Raporu.pdf, $\quad$ adresinden 05.09.2020 tarihinde alınmıştır.

Yavuz, M., \& Gülmez, D. (2016). The assessment of service quality perception in higher education. Education and Science, 41(184), 251-265.

Yel, Ş.Y. (2014). Neoliberalizm ve küreselleşme ekseninde beyaz yakalı emeğin dönüşümü: Nazilli'de özel dershanelerde çalışan ögretmenler üzerine bir araştırma. (Yayımlanmamış yüksek lisans tezi). Aydın Adnan Menderes Üniversitesi, Sosyal Bilimler Enstitüsü. Aydın.

YÖDEK. (2006). Yükseköğretim kurumlarında akademik değerlendirme ve kalite geliştirme yönetmeliği. http://www.yodek.org.tr/, adresinden 07.06.2020 tarihinde alınmıştır.

YÖDEK. (2007). Yükseköğretim kurumlarında akademik değerlendirme ve kalite geliştirme rehberi. http://www.yodek.org.tr/, adresinden 02.06.2020 tarihinde alınmıştır. 
YÖK. (2019a). 2018 yüksekögrretim değerlendirme ve kalite güvencesi durum raporu. Ankara: Yükseköğretim Kalite Kurulu.

YÖK. (2019b). 2019 yll YKS istatistikleri. https://istatistik.yok.gov.tr/, adresinden 7.06.2020 tarihinde alınmıştır.

YÖK. (2015). Yükseköğretim kalite güvencesi ve yükseköğretim kalite kurulu yönetmeliği. 23 Temmuz 2015 Perşembe Resmî Gazete Sayı: 29423.

YÖK. (2018a). Yükseköğretim kalite güvencesi ve yükseköğretim kalite kurulu yönetmeliği. 23 Kasım 2018 CUMA Resmî Gazete Say1: 30604.

YÖK. (2018b). 2018 yll istatistikleri. https://istatistik.yok.gov.tr/, adresinden 7.06.2020 tarihinde alınmıştır.

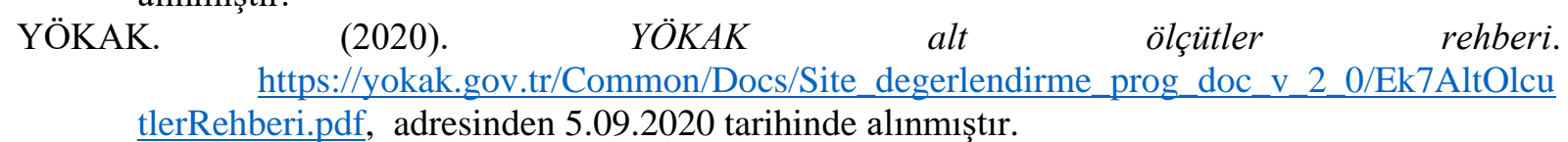

\section{Extended Abstract}

\section{Introduction}

Quality in education is one of the issues that students, teachers, educational institutions and society attach importance to recently. With globalization, the expectation of qualified service and human resources has emerged in the society. This expectation has brought a quality-oriented management approach to the agenda in all educational institutions as well as higher education institutions. Factors that affect quality in higher education can be listed as teaching staff, management, university-industry cooperation, employment status, physical and social opportunities, education program and student. The purpose of this research is to determine the views of university students regarding the quality indicators in higher education.

\section{Methodology}

The research is designed in survey model. In the research, was used easily accessible sampling method, which is one of the purposeful sampling methods. The participants of the research consist of students studying at vocational colleges at Kurklareli University in 2017-2018 academic year. The sample of the research consists of 1200 students. As the data collection tool, was used the "Determination of the Views of the Faculty of Education Students on Quality in Higher Education Scale" developed by Meraler (2011). The scale consists of 6 dimensions. These dimensions are "students", "teaching staff", "learningteaching process", "facilities, library and technology centers", "management" and "scientific and social activities". The data collection tool consists of 51 items. In the analysis of research data, arithmetic mean $(\overline{\mathrm{x}})$, standard deviation (ss) techniques, t-test and one-way analysis of variance (ANOVA) tests were used. Initially, were determined students' opinions about quality in higher education. Then, it was examined whether the opinions of the students regarding the quality indicators in higher education differ significantly according to the demographic characteristics of the students.

\section{Findings and Discussion}

According to the research findings, the most important quality indicators in higher education are listed as "facilities, library and technology centers", "management", "teaching-learning process", "scientific and social activities", "students" and "teaching staff".

According to the research findings, the following are stated as the most important quality indicators in higher education; Education service for students with disabilities, satisfaction levels of students, teaching staffs give importance to students and support student achievements, The use of new teaching technologies in teaching-learning processes, is an effective communication between teaching staffs and students.

In addition, it has been stated as quality indicators that teaching environments such as classrooms, workshops and laboratories are adequate and well-maintained, university management takes into account students' problems and opinions, and that university management has positive relations with all its staff. In addition, the quality indicators are listed as follows: The democratic environment at the university, the world ranking of the university, the number of awards the university has in various fields, the contribution it provides to the society, student counseling services, the level of social and cultural opportunities. According to the findings of the research, the opinions of students regarding the quality in higher education do not differ according to their demographic characteristics. 
According to the research result, in order to improve the quality in higher education, there is a need for important studies in terms of facilities, library and technology centers, management, teaching-learning process, scientific and social activities, students and teaching staffs.

It may be beneficial to take of student views and follow quality-oriented policies in higher education. In Turkey, the higher education system should be reconsidered as a holistic approach and employmentoriented. In particular, there is a need to follow the policies that focus on improving the physical facilities of vocational colleges and increasing the effectiveness of the teaching-learning process, and the approaches that focus on students' interests, expectations, satisfaction and demands.

\footnotetext{
* Araştırma verilerinin toplanmasına katkı sağlayan Öğr. Gör. Yeşim Can ve Öğr. Gör. Beste Burcu Kasap ile verilerin analizi sürecindeki desteğinden dolayı Öğr. Gör. Bülent Kılıç'a teşekkür ederim.
} 